\title{
Efficacy of Sea Weed Extract-Sagarika (Liquid) for Enhancing the Productivity of Green Gram (Vigna radiata L.)
}

\author{
S. C. Alagundagi* \\ IFFCO-Chair, UAS, Dharwad, Karnataka, India \\ *Corresponding author
}

\section{A B S T R A C T}

\begin{tabular}{l} 
Ke y w o r d s \\
$\begin{array}{l}\text { Green Gram } \\
\text { (Vigna radiata } \text { L.), } \\
\text { of Sea Weed } \\
\text { Extract-Sagarika }\end{array}$ \\
\hline Article Info \\
$\begin{array}{l}\text { Accepted: } \\
\text { 22 June } 2020 \\
\text { Available Online: } \\
\text { 10 July } 2020\end{array}$ \\
\hline
\end{tabular}

A field experiment on green gram was conducted during kharif 2018 and 2019 at UAS Dharwad, Karnataka on clayey soil. The experiment consisted of seven treatments including seed treatment and foliar spray of sea weed extract-Sagarika (liquid) along with recommended seed treatment. The Sagarika was sprayed once or twice along with recommended seed treatment and NPK consortia. It was sprayed at pre flowering and pod formation stages. The experiment was replicated thrice under Randomized Complete Block Design. The pooled results indicated that all the treatments involving Sagarika were significantly on par with each other. The treatment, $\operatorname{RDF}\left(25: 50 \mathrm{~kg} \mathrm{NP} \mathrm{ha}^{-1}\right)+$ recommended seed treatment (Rhizobium+ PSB) + Sagarika @ $0.1 \%$ seed soaking + Sagarika@0.25\% foliar spray at pre flowering stage recorded significantly higher seed yield $\left(880 \mathrm{~kg} \mathrm{ha}^{-1}\right)$ and net returns (Rs.34534 ha ${ }^{-1}$ ) followed by RDF with NPK consortia seed coating @ $10 \mathrm{ml} / \mathrm{kg}$ seed + Sagarika @ $0.25 \%$ foliar spray at pre flowering stage (874 kg ha ${ }^{-1}$ and Rs. 34320 ha $^{-1}$, respectively) and RDF with recommended seed treatment + Sagarika @ $0.1 \%$ for seed soaking ( $827 \mathrm{~kg} \mathrm{ha}^{-1}$ and Rs. $31923 \mathrm{ha}^{-1}$, respectively).

\section{Introduction}

Green gram (Vigna radiata L.) is the third most important food legumes grown and consumed in India and is also an important kharif legume of northern Karnataka. It is sown along with onset of monsoon. Normally farmers do not apply the recommended fertilizers including seed treatment because of its shorter duration. Though the productivity is low, they value this crop for leaf fall and the subsequent advantages to the succeeding crop. The simple and low cost production technologies like seed treatment and foliar nutrition can boost the productivity, increasing the monetary benefits. There are reports that sea weed extracts as organic biostimulants is fast becoming accepted practice due to its beneficial effects (Verkleij, 1992). In green gram, sea weed extract enhanced the seed germination and performance of growth and yield parameters (Kavipriya et al., 2011). This technology is simple and cost effective. Keeping in view the beneficial effects of sea weed extract, the study was initiated with Sagarika (liquid) with the following objectives include effect of sagarika foliar spray along with recommended seed treatment on growth and yield of green gram. And also study about economic analysis of 
the system.

\section{Materials and Methods}

A field experiment was conducted at UAS Dharwad, Karnataka during kharif 2018 and 2019 in Northern transition zone of Karnataka under clayey soil. The soil was having low available nitrogen (243 $\mathrm{kg} \mathrm{ha}^{-1}$ ), medium available phosphorus (27 $\left.\mathrm{kg} \mathrm{ha}{ }^{-1}\right)$ and medium available potassium $\left(263 \mathrm{~kg} \mathrm{ha}^{-1}\right)$ with neutral $\mathrm{pH}$. The experiment consisted of seven treatments replicated thrice in Randomized Complete Block Design. The green gram variety used was DGGV-2. The treatments consisted of $\mathrm{T}_{1}: \mathrm{RDF}(25: 50 \mathrm{~kg} \mathrm{NP}$ $\mathrm{ha}^{-1}$ ) with recommended seed treatment (Rhizobium@500 g + PSB @ $1250 \mathrm{~g} \mathrm{ha}^{-1}$ ), $\mathrm{T}_{2}$ : RDF with NPK consortia seed coating @ $10 \mathrm{ml} / \mathrm{kg}$ seed, $\mathrm{T}_{3}: \mathrm{T}_{2}+$ Sagarika @ $0.25 \%$ (one spray), $\mathrm{T}_{4}: \mathrm{T}_{2}+$ Sagarika @ 0.25\% (two spray), $\mathrm{T}_{5}: \mathrm{T}_{1}+$ Sagarika @ $0.1 \%$ (seed soaking for $30 \mathrm{~min}), \mathrm{T}_{6}: \mathrm{T}_{5}+$ Sagarika @ 0.25 $\%$ (one spray) and $\mathrm{T}_{7}: \mathrm{T}_{5}+$ Sagarika @ 0.25 $\%$ (two spray) at pre flowering and pod formation stages. The biometric observations were recorded at peak growth stage and yield parameters at maturity. Recommended cultivation practices were followed for all the treatments along with RDF.

\section{Results and Discussion}

\section{Growth and yield attributes (cf. Table 1 and 2)}

The pooled data indicated that the seed yield of green gram was significantly influenced by all the sea weed extract-Sagarika involving treatments compared to recommended seed treatment (Rhizobium and PSB) and NPK consortia seed coating. However, all the treatments $\left(\mathrm{T}_{3}-\mathrm{T}_{7}\right)$ involving liquid Sagarika (sea weed extract) recorded significantly higher seed yield $\left(810-880 \mathrm{~kg} \mathrm{ha}^{-1}\right)$. The treatment $\mathrm{T}_{6}$, involving $\mathrm{RDF}+$ recommended seed treatment (Rhizobium+ PSB) + Sagarika @ $0.1 \%$ seed soaking + Sagarika @ $0.25 \%$ foliar spray at pre flowering stage recorded significantly higher green gram seed yield of $880 \mathrm{~kg} \mathrm{ha}^{-1}$ followed by $\mathrm{T}_{3}$, involving RDF with NPK consortia seed coating @ $10 \mathrm{ml} / \mathrm{kg}$ seed + Sagarika@ $0.25 \%$ foliar spray at pre flowering stage $\left(874 \mathrm{~kg} \mathrm{ha}^{-1}\right)$ and $\mathrm{T}_{5}$ i.e., $\mathrm{RDF}$ with recommended seed treatment (Rhizobium + PSB)+Sagarika@0.1\% for seed soaking $\left(827 \mathrm{~kg} \mathrm{ha}^{-1}\right)$.

The seed yield was significantly lower with only recommended biofertizer treatment and NPK consortia seed coating. The higher seed yield of green gram recorded with Sagarika (sea weed extract) treatments was due to better performance of growth and yield parameters viz., plant height $(68.0-76.8 \mathrm{~cm})$, number of branches (4-5 per plant), number of pods (11.8-14.8 per plant) and seed yield (11.0-14.6 $\mathrm{g}$ per plant). Similar trend followed during 2018 and 2019.

However, seed yield per plant and per ha were non significant during 2018. These results are in conformity with the findings of Kavipriya et al., (2011) who obtained better seed germination and growth parameters in green gram with sea weed extract as a bio-stimulant. Zodape et al., (2010) also reported significantly increased seed yield and yield parameters over control with sea weed extract applied treatments in green gram.

Saishankar (2001) stated that, foliar spray with NAA@ @ 40 ppm in green gram, twice at the time of flowering and 15 days after flowering increased the plant height, number of branches and flowers per plant over control. Sujatha (2001) reported that, foliar application of salicylic acid $(100 \mathrm{ppm})$ on green gram at 75 days after sowing increased the number of pods per plant, number of seeds per pod, seed weight per plant, 100 seed weight and grain yield $\left(840 \mathrm{~kg} \mathrm{ha}^{-1}\right)$. 
Table.1 Growth and yield parameters of green gram as influenced by sea weed extract-Sagarika (liquid)

\begin{tabular}{|c|c|c|c|c|c|c|c|c|c|c|c|c|}
\hline \multirow[t]{2}{*}{ Treatment } & \multicolumn{3}{|c|}{ Plant height (cm) } & \multicolumn{3}{|c|}{ Number of branches per plant } & \multicolumn{3}{|c|}{ Number of pods per plant } & \multicolumn{3}{|c|}{ Seed yield $\left(\mathrm{g} \mathrm{plant}^{-1}\right)$} \\
\hline & 2018 & 2019 & Pooled & 2018 & 2019 & Pooled & 2018 & 2019 & Pooled & 2018 & 2019 & Pooled \\
\hline $\begin{array}{c}\mathrm{T}_{1}: \mathrm{RDF} \text { with recommended seed } \\
\text { treatment }\end{array}$ & 67.7 & 58.6 & 63.1 & 4.0 & 4.0 & 4.0 & 13.2 & 8.3 & 10.8 & 12.0 & 9.2 & 10.6 \\
\hline $\begin{array}{c}\mathrm{T}_{2}: \text { RDF with NPK Consortia seed } \\
\text { coating @ } 10 \mathrm{ml} / \mathrm{kg} \text { seed }\end{array}$ & 63.7 & 61.4 & 62.5 & 4.0 & 4.0 & 4.0 & 13.0 & 8.0 & 10.5 & 11.7 & 9.8 & 10.8 \\
\hline $\mathrm{T}_{3}: \mathrm{T}_{2}+$ Sagarika @0.25\% (one spray) & 76.7 & 62.5 & 69.6 & 5.0 & 5.0 & 5.0 & 18.5 & 9.7 & 14.1 & 17.0 & 11.5 & 14.3 \\
\hline $\mathrm{T}_{4}: \mathrm{T}_{2}+$ Sagarika @0.25\% (two spray) & 73.5 & 65.4 & 69.5 & 4.0 & 3.0 & 3.0 & 14.0 & 10.3 & 12.2 & 13.9 & 9.7 & 11.8 \\
\hline $\begin{array}{c}\mathrm{T}_{5}: \mathrm{T}_{1}+\text { Sagarika @ } 0.1 \%(\text { seed } \\
\text { soaking for } 30 \mathrm{~min})\end{array}$ & 76.3 & 68.5 & 72.4 & 4.0 & 4.3 & 4.0 & 15.0 & 8.7 & 11.8 & 15.9 & 9.7 & 12.8 \\
\hline $\mathrm{T}_{6}: \mathrm{T}_{5}+$ Sagarika @0.25\% (one spray) & 80.2 & 73.4 & 76.8 & 4.0 & 5.0 & 4.0 & 20.3 & 9.3 & 14.8 & 17.2 & 11.9 & 14.6 \\
\hline $\mathrm{T}_{7}: \mathrm{T}_{5}+$ Sagarika @0.25\% (two spray) & 72.8 & 63.2 & 68.0 & 4.0 & 3.7 & 4.0 & 13.8 & 11.0 & 12.4 & 12.1 & 9.9 & 11.0 \\
\hline S.Em. \pm & 3.76 & 5.88 & 3.66 & 0.48 & 0.44 & 0.35 & 1.92 & 0.87 & 1.25 & 3.10 & 0.67 & 1.24 \\
\hline C.D. $(P=0.05)$ & 11.58 & NS & 11.27 & NS & 1.36 & 1.09 & 5.91 & 2.67 & 3.84 & NS & 2.07 & 3.65 \\
\hline
\end{tabular}

Note: Foliar spray: $1^{\text {st }}$ at pre flowering and $2^{\text {nd }}$ at pod formation stage

Table.2 Seed and haulm yield of green gram as influenced by sea weed extract-Sagarika (liquid)

\begin{tabular}{|c|c|c|c|c|c|c|c|c|c|}
\hline \multirow[b]{2}{*}{ Treatment } & \multicolumn{3}{|c|}{ Seed yield $\left(\mathrm{kg} \mathrm{ha}^{-1}\right)$} & \multicolumn{3}{|c|}{ Haulm yield $\left(\mathrm{kg} \mathrm{ha}^{-1}\right)$} & \multicolumn{3}{|c|}{ Harvest Index (\%) } \\
\hline & 2018 & 2019 & Pooled & 2018 & 2019 & Pooled & 2018 & 2019 & Pooled \\
\hline $\begin{array}{l}T_{1}: \text { RDF with recommended seed } \\
\text { treatment }\end{array}$ & 893 & 606 & 750 & 527 & 506 & 517 & 62.79 & 54.48 & 58.64 \\
\hline $\begin{array}{l}T_{2}: \text { RDF with NPK Consortia seed } \\
\text { coating@10 ml/kg seed }\end{array}$ & 871 & 584 & 728 & 524 & 497 & 511 & 62.53 & 53.89 & 58.21 \\
\hline $\mathrm{T}_{3}: \mathrm{T}_{2}+$ Sagarika @0.25\% (one spray) & 1006 & 742 & 874 & 506 & 529 & 517 & 66.97 & 58.24 & 62.61 \\
\hline $\mathbf{T}_{4}: \mathrm{T}_{2}+$ Sagarika@0.25\% (two spray) & 996 & 651 & 823 & 483 & 493 & 488 & 67.31 & 56.83 & 62.07 \\
\hline $\begin{array}{l}T_{5}: T_{1}+\text { Sagarika @ } 0.1 \% \text { (seed soaking } \\
\text { for } 30 \mathrm{~min})\end{array}$ & 1002 & 653 & 827 & 568 & 526 & 547 & 63.84 & 55.22 & 59.53 \\
\hline$T_{6}: T_{5}+$ Sagarika @0.25 \% (one spray) & 1038 & 722 & 880 & 523 & 511 & 517 & 66.41 & 58.53 & 62.47 \\
\hline $\mathrm{T}_{7}: \mathrm{T}_{5}+$ Sagarika @0.25\% (two spray) & 979 & 642 & 810 & 489 & 475 & 482 & 67.14 & 57.17 & 62.16 \\
\hline S.Em.土 & 69 & 38 & 40 & 57 & 30.11 & 23.35 & 2.43 & 2.31 & 1.21 \\
\hline C.D. $(P=0.05)$ & NS & 119.0 & 118 & NS & NS & NS & NS & NS & 3.58 \\
\hline
\end{tabular}

Note: Foliar spray: $1^{\text {st }}$ at pre flowering and $2^{\text {nd }}$ at pod formation stage 
Table.3 Economic parameters of green gram cultivation as influenced by sea weed extract-Sagarika (liquid)

\begin{tabular}{|c|c|c|c|c|c|c|c|c|c|c|c|}
\hline Treatment & \multicolumn{2}{|c|}{$\begin{array}{c}\text { Cost of } \\
\text { cultivation } \\
\left(\text { Rs. ha }{ }^{-1}\right)\end{array}$} & \multicolumn{3}{|c|}{$\begin{array}{l}\text { Gross returns } \\
\quad\left(\text { Rs. } \mathbf{h a}^{-1}\right)\end{array}$} & \multicolumn{3}{|c|}{$\begin{array}{l}\text { Net returns } \\
\left(\text { Rs. ha }{ }^{-1}\right)\end{array}$} & \multicolumn{3}{|c|}{ B:C ratio } \\
\hline $\begin{array}{c}\mathrm{T}_{1}: \mathrm{RDF} \text { with } \\
\text { recommended seed } \\
\text { treatment }\end{array}$ & 21725 & 21855 & 54376 & 43258 & 48817 & 32651 & 21403 & 27027 & 2.50 & 1.98 & 2.24 \\
\hline 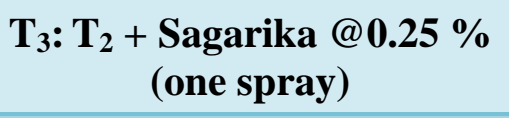 & 22560 & 22710 & 61100 & 52811 & 56955 & 38540 & 30101 & 34320 & 2.71 & 2.33 & 2.52 \\
\hline $\begin{array}{c}\mathbf{T}_{4}: \mathbf{T}_{2}+\underset{\text { Sagarika @ } 0.25 \%}{\text { (two spray) }} \\
\text { (woy }\end{array}$ & 23385 & 23495 & 60459 & 46382 & 53420 & 37074 & 22887 & 29980 & 2.59 & 1.97 & 2.28 \\
\hline $\begin{array}{c}\mathbf{T}_{6}: \mathbf{T}_{5}+\begin{array}{c}\text { Sagarika @ } \\
\text { (one spray) }\end{array} \\
0.25 \% \\
\text { \% }\end{array}$ & 22600 & 22730 & 63067 & 51331 & 57199 & 40467 & 28601 & 34534 & 2.79 & 2.26 & 2.52 \\
\hline 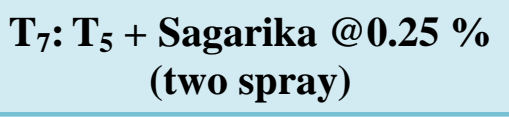 & 23425 & 23535 & 59489 & 45670 & 52579 & 36064 & 22135 & 29099 & 2.54 & 1.94 & 2.24 \\
\hline S.Em.土 & & & 3368 & 2676 & 2233 & 3368 & 2676 & 2233 & 0.15 & 0.12 & 0.10 \\
\hline C.D. $(P=0.05)$ & & & NS & 8247 & 6881 & NS & 8247 & 6881 & NS & 0.36 & 0.31 \\
\hline
\end{tabular}

Note: 1) Foliar spray: $1^{\text {st }}$ at pre flowering and $2^{\text {nd }}$ at pod formation stage 2) Selling price: Seeds-Rs.60/kg, Haulm-Rs. 1500/t 
Fig.1 High yielding treatments $\mathrm{T}_{6}$ : RDF with recommended seed treatment +Sagarika @0.1\% (seed soaking for 30 min) + Sagarika @ $0.25 \%$ (one spray)

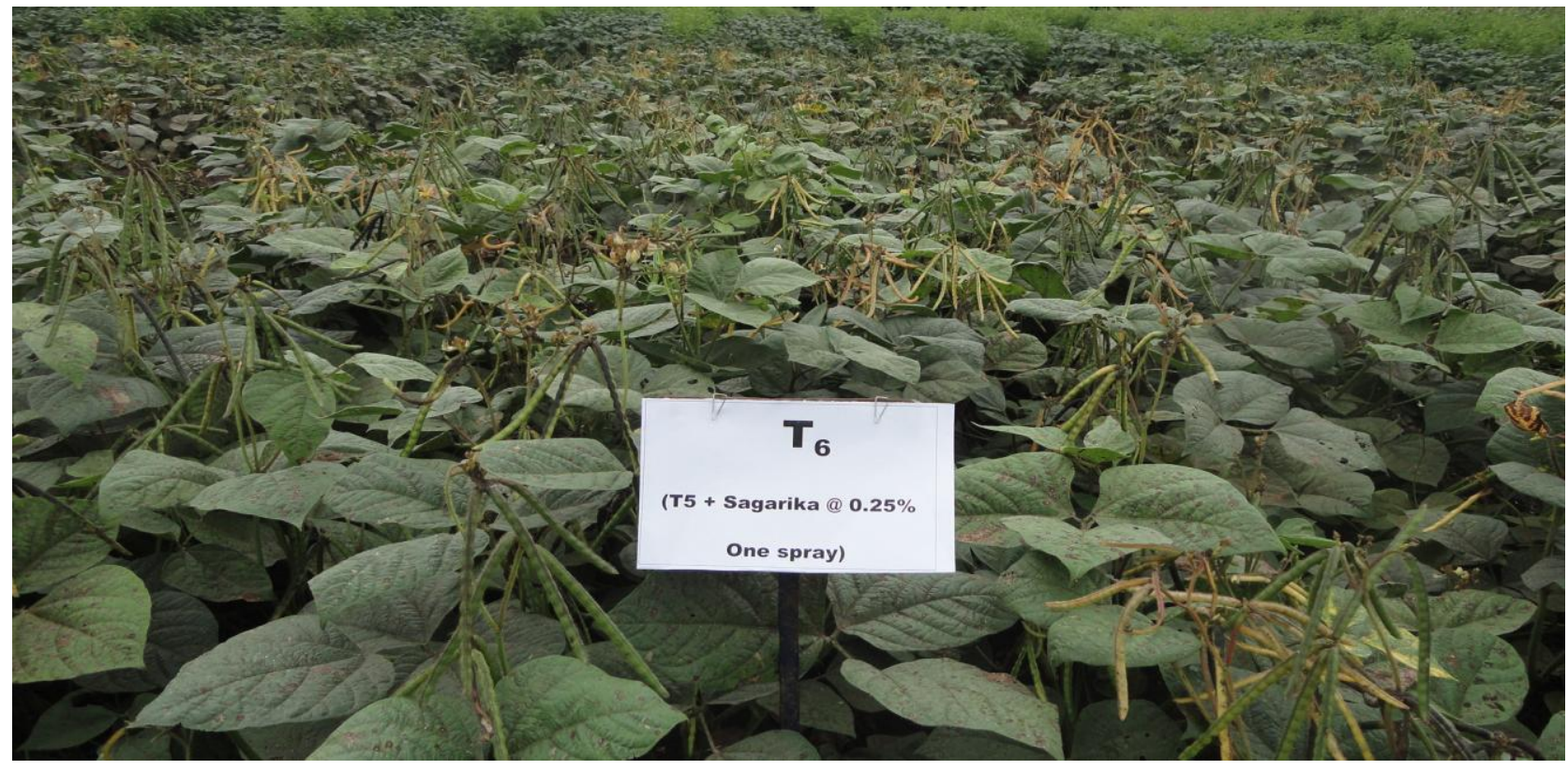

Fig.2 $\mathrm{T}_{3}$ : RDF with NPK Consortia seed coating @10 ml/kg seed + Sagarika @ 0.25\% (one spray)

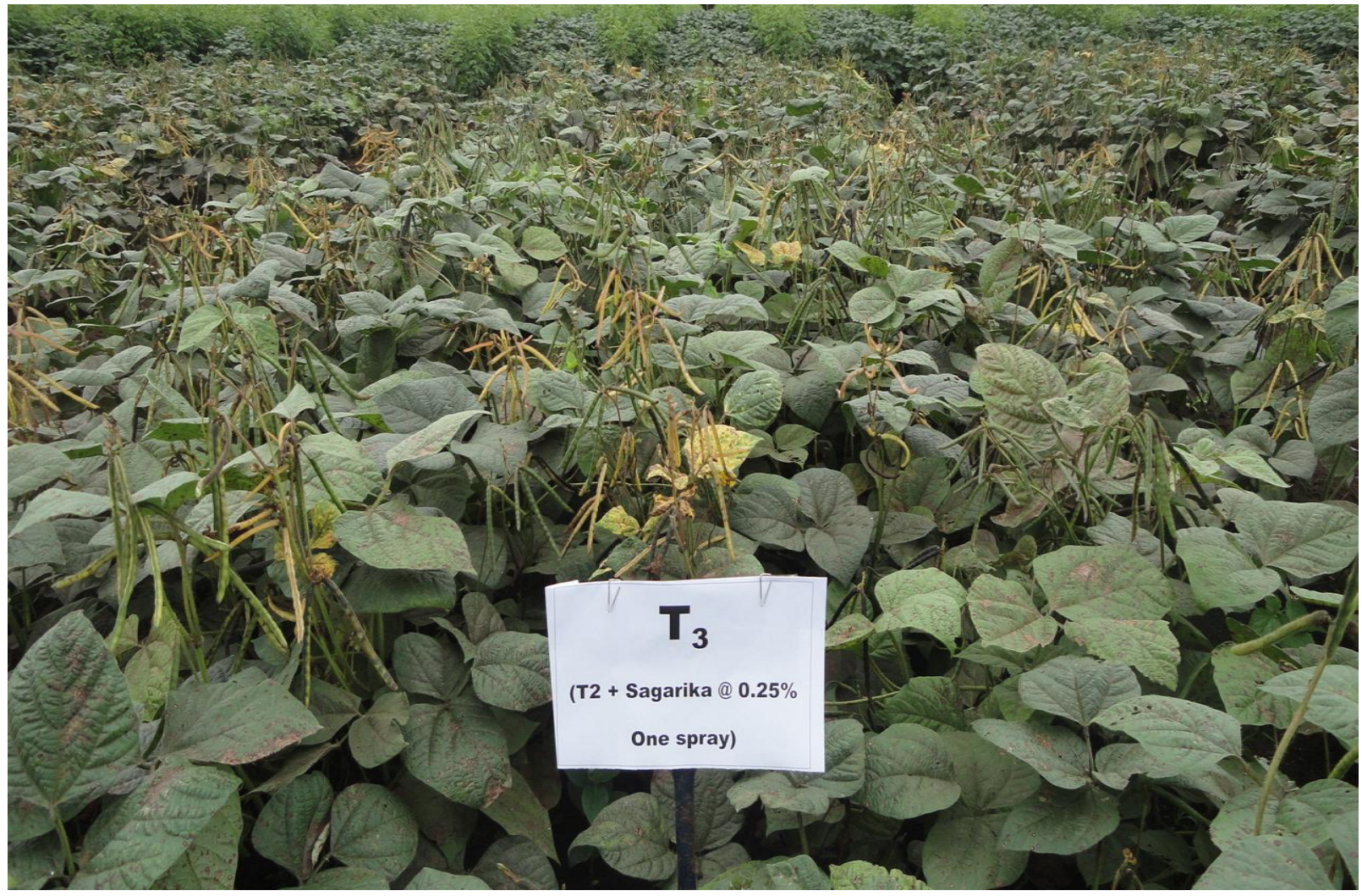


Fig.3 $\mathrm{T}_{5}$ : RDF with recommended seed treatment + Sagarika @ $0.1 \%$ (seed soaking for 30 min)

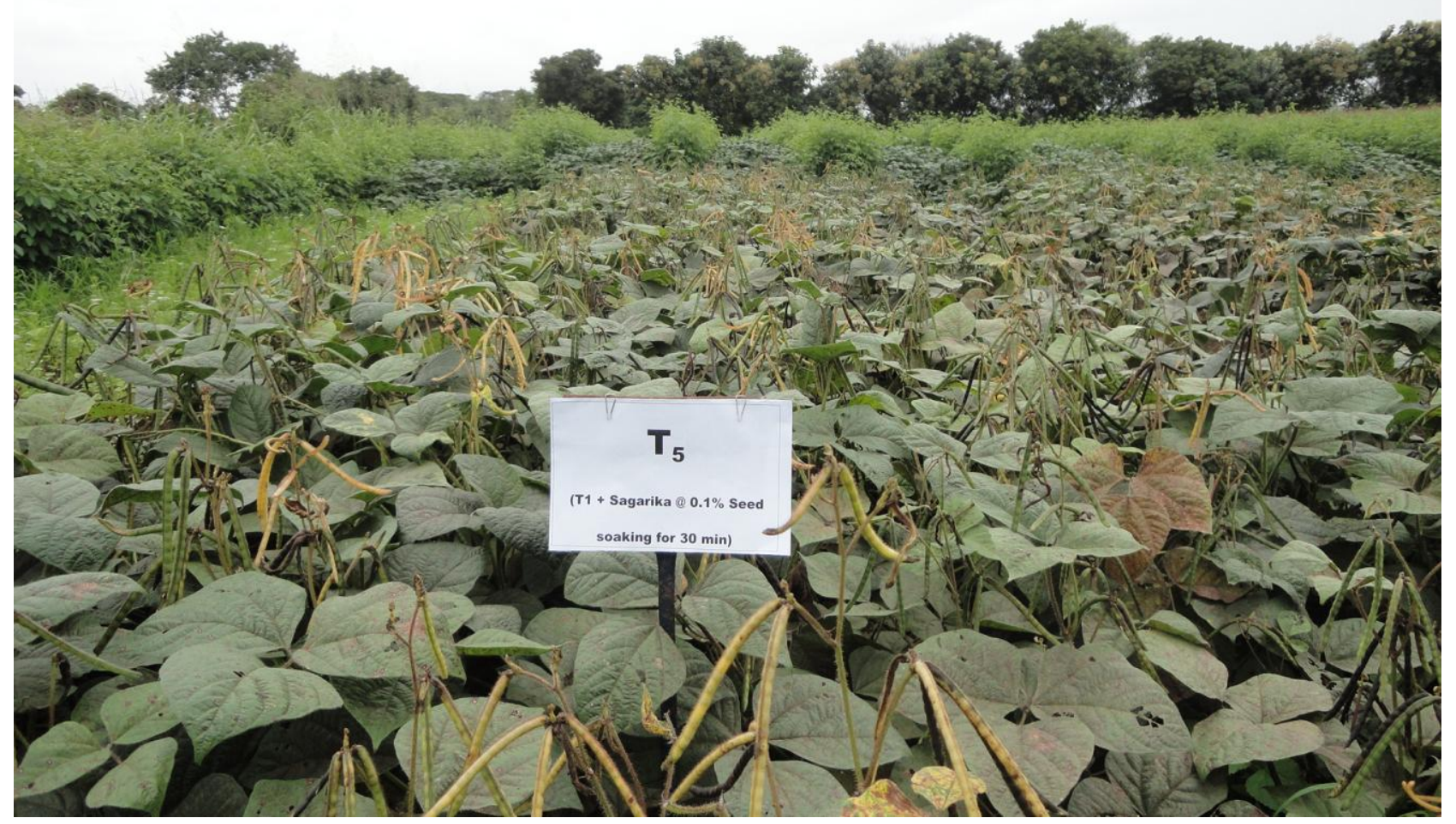

The haulm yield did not show significant effect due to treatments. However, pooled data showed that, it ranged from $482-547 \mathrm{~kg}$ $\mathrm{ha}^{-1}$. This indicated the influence of sea weed extract-Sagarika more on reproductive phase of the crop.

\section{Economics (cf. Table 3)}

The monetary indicators followed the similar trend of seed yield. All the treatments involving Sagarika recorded significantly higher gross and net returns and were on par with each other. The treatments (pooled results) involving sea weed extract-Sagarika (liquid) recorded significantly higher net returns (Rs. 29099-34534 ha ${ }^{-1}$ ) and B:C ratio (2.24-2.52) compared to only biofertilizer or NPK consortia application treatments. The increased monetory benefits were due to higher seed yield recorded with these treatments. These results are in conformity with the findings of Dixit and Elamathi
(2007) in green gram with foliar spray of DAP 2.0 per cent + NAA 40 ppm + B 0.2 per cent + Mo 0.05 per cent at 30 DAS resulting in higher benefit cost ratio (1.97) over control (1.45).

In conclusion,

Irrespective of seed soaking or foliar spray, the productivity of green gram was enhanced with application of sea weed extract-Sagarika (liquid).

$\mathrm{RDF}+$ recommended seed treatment (Rhizobium+ PSB) + Sagarika @ $0.1 \%$ seed soaking + Sagarika@0.25\% foliar spray at pre flowering stage recorded significantly higher seed yield $\left(880 \mathrm{~kg} \mathrm{ha}^{-1}\right)$ and net returns (Rs.34534 ha-1) followed by RDF with NPK consortia seed coating @ $10 \mathrm{ml} / \mathrm{kg}$ seed + Sagarika @ $0.25 \%$ foliar spray at pre flowering stage (874 kg ha ${ }^{-1}$ and Rs.34320 ha ${ }^{1}$, respectively) and RDF with recommended 
seed treatment + Sagarika@0.1\% for seed soaking (827 kg ha ${ }^{-1}$ and Rs.31923 ha ${ }^{-1}$, respectively).

Since sea weed extract is eco-friendly and cheaper, it can be promoted along with biofertilizer as a bio-stimulant.

\section{References}

Dixit, P. M. and Elamathi, S., 2007, Effect of foliar application of DAP, micronutrients and NAA on growth and yield of green gram (Vigna radiata L.). Legume Res., 30(4): 305-307.

Kavipriya, R., Dhanalakshmi, P. K., Jayashree, S. and Thangaraju, N., 2011, Seaweed extract as a biostimulant for legume crop-green gram. J. Ecobiotech., 3(8): 16-19.
Saishankar, S., 2001, Influence of plant growth regulators, chemicals and nutrients in green gram [Vigna radiata (L.) Wilczek]. M.Sc. (Agri.) Thesis, Univ. Agric. Sci., Dharwad, Karnataka (India).

Sujatha, K. B., 2001, Effect of foliar spray of chemical and bioregulators on growth and yield of green gram (Vigna radiata $\mathrm{L}$.). M.Sc. (Agri.) Thesis, Tamil Nadu Agric. Univ., Coimbatore.

Verkleij, F. N., 1992, Sea weed extracts in agriculture and horticulture -A review. Biol. Agric. Horti. 8: 37-48.

Zodape, S.T., Soumitha, M., Eswaran, K., Reddy, M.P. and Chikara, J., 2010, Enhanced yield and nutritional quality in green gram treated with sea weed extract. J. Scientific Industrial Res., 69:468-471.

\section{How to cite this article:}

Alagundagi, S. C. 2020. Efficacy of Sea Weed Extract-Sagarika (Liquid) for Enhancing the Productivity of Green Gram (Vigna radiata L.). Int.J.Curr.Microbiol.App.Sci. 9(07): 33513357. doi: https://doi.org/10.20546/ijcmas.2020.907.391 